\title{
To What Extent A Sustainability Strategy Of Supply Chain Management Is Applied In University?
}

\author{
Achmad Hidayat Sutawidjaya \\ Doctorate Program of Management, \\ Universitas Mercu Buana, Indonesia
}

\author{
Lenny Ch Nawangsari \\ Postgraduate Program of Management \\ Universitas Mercu Buana, Indonesia
}

\begin{abstract}
Today's the business world faces one of the world's toughest challenges of VUCA (Volatility, Uncertainty, Complexity \& Ambiguity) of the world. Dynamic conditions, uncertainty and complexity are required for most business practices, including universities, to improve and maintain their organizational strategies. Supply Chain Management (SCM) is become the primary role in organizations to maintain their practices. By applying the effective Supply Chain system, it is expected that universities can perform campus service activities in an efficient, qualified, fast, flexible and innovative way. This study aims to create a Supply Chain Management Strategy framework at the University. The research methodology is used the qualitative approaches. The data collection will be taken through deep interviews and detail observations on key informants and then analyze the data and draw conclusions by reduction. This study highlights that the four-stage model of the Supply Chain Management Framework of the University. The first stage is called "strategy analysis of supply chain" consisting of identifying market needs and integrating organizational vision $\&$ mission with strategy of supply chain. The second phase is the "strategy formulation of supply chain", at this stage a supply chain strategy is created which focuses on providing services for customer needs for low cost, quality, timely and diverse products. The third stage is "strategy implementation of supply chain" which consists of input, process and output and the last step is "evaluation Strategy of supply chain". The whole process refers to the business of sustainability. Supply Chain Management in universities is expected could improve the efficiency and effectiveness of the organization to achieve corporate goals and create strategic values that can determine the sustainability of the company.
\end{abstract}

Keywords-Strategy, Sustainability, Supply Chain Management, University

\section{INTRODUCTION}

The phenomenon of disruption or change in perspective and business fundamentals, one of which is due to the revolution in technology and is predicted to take place within the next 100 years. If a company still maintains an old business model, sooner or later it will be sure to get disrupted. These changes provide opportunities as well as challenges for each organization, including universities to be able to maintain the business values contained in the organization.
Sustainability is a process of the organization's ability to maintain and protect a company from time to time. The sustainability of a business other than the environment also covers the fields of law, finance, economics, industry, social, material and behavior. In the world of education the concept of sustainability and supply chain into two global issues now demands changes in educational institutions both in facilities, educational structures and curriculum, research and community service. Sustainability "meeting the needs of the present without compromising the ability of future generations to meet their own needs" (WCED, 1987). While the Supply Chain Management (SCM) is a physical network that consists of a series of companies that are involved in supplying raw materials, produce goods, and send it to the customer or end user. Operations in the supply chain require a continuous flow of information to produce good products at the right time according to the needs of consumers. According [2], successful supply chain management requires an integrated system. Each unit in the supply chain becomes one, not standalone as is the case with traditional supply chains.

For owners and managers of educational institutions, a quality management system should lead to continuous improvement to strengthen and develop all aspects of that quality [1]. An important issue that must be considered is how university management is regulated in a system that makes education activities efficient and effective so that the vision and objectives of the university's existence can be achieved. To support this success, an integrated concept is needed from starting upstream and downstream simultaneously.

Habib in his research said supply chain management to shed lights on education and research supply chain components and how they may be operated and coordinated to achieve the goals. [4], Chamnong Jungthirapanich, Proceedings of the IEEE ICMIT, 2008). Beside that Gopala Krishnan in his research "how to apply academic supply chain management: the case of an international university" identify the application of SCM in RMIT University Vietnam first identify the upstream and downstream activities at RMIT University Vietnam with reference to the ITESCM (Integrated Tertiary Educational Supply Chain Management) model developed by Hab ib and Jungthirapanich (2008). It will then do a thorough analysis of the internal and external environment. Finally, based on the analysis, this paper will 
apply the Supply Chain Operations Reference (SCOR) model developed by the Supply - Chain Council to b uild a robust supply chain relationship for RMIT Vietnam [3].

This paper contains the integration of the sustainability strategy from Supply Chain Management into education at the University.

\section{METHOD AND DATA COLLECTION}

The research method used in this research is qualitative research with a case study approach. According to Yin (2011: 1 ), in general, case studies are strategies that are more suitable when the subject of a research question. The object of this study was this research conducted at Mercu Buana University.

Data collection techniques in qualitative research are observation, focus group discussion (FGD), in-depth interviews and case studies [7]. The initial stage the researcher chooses a particular person as the informant who is considered will provide the required data. Furthermore, based on the data or information obtained from the previous sample, researchers can specify other samples that are considered to provide more complete data.

\section{RESULT AND DISCUSSION}

In this study, respondents consisted of active stakeholders at the University of Indonesia in Jakarta. Supply chain is a set of activities involved in the process of transformation and distribution of goods ranging from the earliest raw materials from nature to finished products to the final consumer. The purpose of Supply Chain Management is to ensure that a product is in the right place and at the right time to meet consumer demand without creating excessive stock or shortage [8].

Increased competition in the world of schools or universities, increasingly complex community demands and the growing number of graduate students from emerging colleges. In order to improve this competitiveness, networks with good integration within a school or university are required. Service companies or businesses in education, students, curriculum, government support (Dikti and Ban PT) and educational suppliers have seen their supply chain as an important area to reduce costs and gain competitiveness [8].

University is a college is an education unit providing higher education. College students are called students, while college educators are called lecturers (Wikepedia). While the University is a higher education and research institution, which provides academic degrees in various fields.

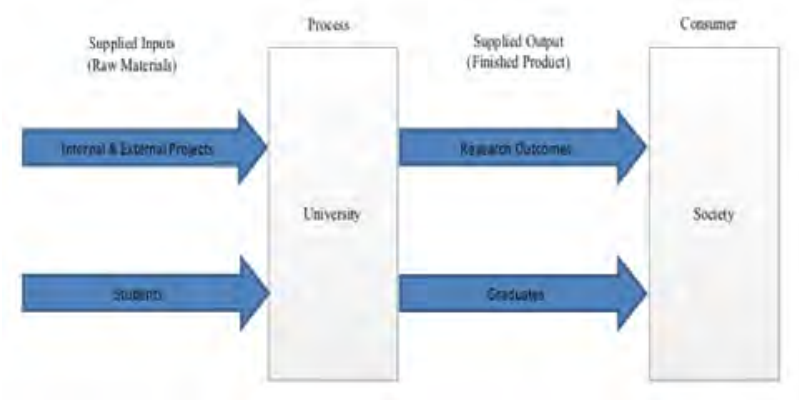

Fig 1. he frame work for research Thinking in the Universityof supply Chain Management

From the picture, it can be explained that the implementation of the Supply Chain Management Framework of the University begins with the "analysis of supply chain strategy" in which the university needs to identify the growing market needs, also adjusted to the vision and mission of the university. The second stage is related to the "strategy formulation of supply chain". This means that companies or universities need to understand the desires and expectations of consumers relating to prices (entering college at university), the quality desired by consumers / society, the timeliness of graduates. And the third stage is the "strategy implementation of supply chain". This stage relates to the readiness of the sources owned by the company, consisting of lecturers, staff, capital, curriculum, buildings, facilities etc. The last stage is the evaluation strategy of supply chain. This stage is related to the overall evaluation stage based on the university's sustainability in the future.

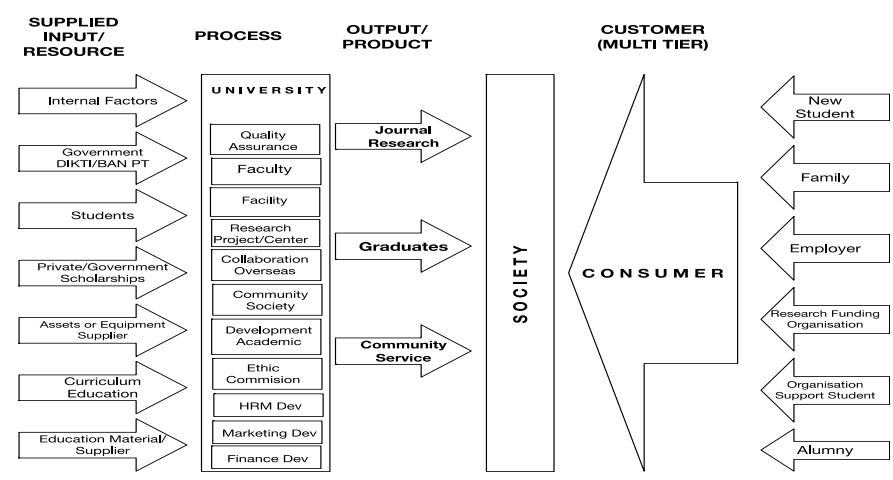

Fig 2. Higher Education Supply Chain Management System Concept

\section{CONCLUSION}

Education is a service-based industry where products are intangible and consumed at the point of production. The focus is now shifting to customers as partners in businesses where they are involved in service delivery. The main customers of Mercu Buana University are students. The value of the customer takes the perspective of the customer's organization, considering what they want and believes they can from buying and using the seller's product. students expect quality learning and they contribute to the production process when their 
feedback is given because of its importance at Mercu Buana University. Student feedback to instructors through the Good Teaching Scale survey is given very important in the renewal of the teaching staff contract.

\section{Acknowledgment}

The author would like to thank Mercu Buana University as the author's informant who helped in providing information related to this research.

\section{References}

[1] Jumadi, Penelitian Tindakan Kelas. (on line) http://www.radarbanjarmasin.com/berita/index.asp?berita=Opini\&id= 71689, 2008

[2] Douglas M. Lambert (2001, 68 - 71), Srategic Logistics Management, Fourth ed, Singapore: McGraw-Hill Higher Education.
[3] Gopalakrishnan. (2015). HOW TO APPLY ACADEMIC SUPPLY CHAIN MANAGEMENT: THE CASE OF AN INTERNATIONAL UNIVERSITY, Management, Vol 20Centre of Commerce and Management, RMIT.

[4] Md. Mamun Habib, Chamnong Jungthirapanich. (2008). An Integrated Framework for Research and Education Supply Chain for the Universities. Proceedings of the IEEE ICMIT

[5] Jay Heizer, Texas Lutheran University, Barry Render, Graduate School of Business, Rollins College.

[6] Robert K Yin, Qualitative Research from Start to Finish, First Edition, 2011

[7] Kriyantono, Rachmat. (2012). "Teknik Praktis Riset Komunikasi Cetakan ke-6". Jakarta: Kencana Prenada Media Group

[8] Sutawidjaya, Achmad Hidayat and Lenny Nawangsari, Global Research Journal, Vol-7, Issue-7, 2018 